Language and Cognition 12 (2020), 729-754. doi:10.1017/langcog.2020.21

(C) UK Cognitive Linguistics Association 2020. This is an Open Access article, distributed under the terms of the Creative Commons Attribution licence (http://creativecommons.org/licenses/ by $/ 4.0 /$ ), which permits unrestricted re-use, distribution, and reproduction in any medium, provided the original work is properly cited.

\title{
The role of non-categorical relations in establishing focus alternative sets*
}

\author{
KIM A. JÖRDENS (i) \\ Institut für deutsche Sprache und Linguistik, Humboldt-Universität zu Berlin \\ NICOLE GOTZNER \\ Leibniz-Zentrum Allgemeine Sprachwissenschaft (ZAS) \\ A N D \\ KATHARINA SPALEK \\ Institut für deutsche Sprache und Linguistik, Humboldt-Universität zu Berlin
}

(Received 18 fune 2019 - Revised 9 May 2020 - Accepted 11 May 2020 -

First published online 5 fune 2020)

\begin{abstract}
A B S T RACT
Categorisation is arguably the most important organising principle in semantic memory. However, elements that are not in a categorical relation can be dynamically grouped together when the context provides a common theme for these elements. In the field of sentence (and discourse) comprehension, alternatives to a focused element can be thought of as a set of elements determined by a theme given in the utterance context. According to Alternative Semantics (Rooth, 1985, 1992), the main function of linguistic focus is to introduce a set of alternatives to the focused element within an utterance. Here, we will investigate the contribution of the utterance context to the composition of focus alternative sets.
\end{abstract}

[*] Kim A. Jördens is now at Leibniz School of Education, Leibniz Universität Hannover. This project has received funding from the European Union's Horizon 2020 research and innovation programme under grant agreement GAP-677742, awarded to Katharina Spalek. The authors would like to thank Felicitas Enders, Xaver Koch, Anna-Lisa Ndao, and Annika Tjuka for their comments and suggestions on the stimulus material, Xaver Koch for assistance in recording the acoustic stimuli, Annika Tjuka for test-running the experiment, Carsten Schliewe for technical assistance, and Pia Knoeferle for providing the laboratory. Portions of this work were submitted as part of the first author's Master's thesis (unpublished). Kim A. Jördens, Humboldt-Universität zu Berlin. Address for correspondence: Kim A. Jördens, Leibniz Universität Hannover, Leibniz School of Education, Appelstraße 9, 30167 Hannover, Germany. E-mail: kim.joerdens@lehrerbildung.uni-hannover.de 


\section{J ÖRDENS ET AL.}

Specifically, we test whether a focus alternative set can contain elements that belong to different taxonomic categories (i.e., that are not closely semantically related). Using a behavioural probe recognition experiment, we show that participants activate elements from another taxonomic category than the focused element as part of sentence comprehension. This finding suggests that the composition of a focus alternative set is not simply based on semantic relations between the members of the set and the focused element, but that contextual relations also play a crucial role.

KEYWORDS: intonation focus, focus alternatives, taxonomic categories, contextual relations, cross-modal priming

\section{Introduction}

Categorisation is an important principle for semantic memory organisation. For example, dog, cat, and mouse are related by their co-membership in the taxonomic category AN I M A LS. Categorical relations are well established in semantic memory and become (immediately) active when words referring to a referent are retrieved from the mental lexicon (see Abdel Rahman \& Melinger, 2011). However, categorical relations are not the only relations relevant for language processing: words from different taxonomic categories can be dynamically and spontaneously grouped together in a given context (e.g., Barsalou, 1982, 1983, 1985, 1991). For example, in an oriental bazaar setting, the differentcategory members figs (FRUIT), carpets (FURNITURE), and cinnamon (S P ICES) might become spontaneously related in a similar way as samecategory members already are because these words refer to oriental commodities that are relevant in the context. Here, we examine the relevance of these so-called ad hoc categories (Barsalou, 2010) during the processing of linguistic focus.

In languages like English and German, focus can be expressed prosodically with pitch accent. Traditionally, focused elements (words or phrases) are said to be intuitively recognised as more important or informative than nonfocused elements (e.g., Büring, 2016). However, according to Alternative Semantics (Rooth, 1985, 1992), the main function of focus is to introduce alternatives to a focused element into the computation of the respective sentence (see also Krifka, 2007). Consider (1), where the subscript $F$ denotes focus and capital letters pitch accent:

\section{(1) The sultan bought $[\mathrm{FIGS}]_{\mathrm{F}}$ at the bazaar.}

A listener processing this sentence might think about alternative fruit, for example, peaches or dates, that the sultan could have bought; these alternative pieces of fruit are considered as focus alternatives. Psycholinguistic research has shown that focus alternatives are not only theoretical constructs proposed 
by the theory of Alternative Semantics (Rooth, 1985, 1992), but that they also have a behavioural reflex (Braun \& Tagliapietra, 2010; Husband \& Ferreira, 2016; see Section 1.3). Still, it remains an open question which specific elements are considered as focus alternatives, that is, how a focus alternative set is composed. So far, there has been evidence that semantically related elements of the same taxonomic category as the focused element, for example peaches and dates in the above-mentioned example, are part of the alternative set (e.g., Spalek \& Oganian, 2019). However, we do not know whether an alternative set can additionally contain elements from different taxonomic categories, for example carpets or cinnamon as alternatives to figs in (1). To set the stage for the present experiment, we will summarise relevant findings on the role of taxonomic and non-taxonomic categories in language processing, the function and realisation of focus, and the processing of focus alternatives.

\subsection{TAX ONOM I C CA TEGORIES}

A category can be defined as a set of objects which are considered equivalent in some respect (Murphy, 2010; Rosch, 1978), whereby the term 'object' is understood in a broad sense, including animate 'objects' as well. Taxonomy refers to the internal structure of a category based on hyponymy (e.g., Cann, 2011; Löbner, 2013; Rosch, 1978). A (simple) hyponym-hyperonym relation can be identified by replacing $\mathrm{x}$ and $\mathrm{Y}$ in the frame $(A) \mathrm{Y}$ is a kind of $\mathrm{x}$ (Cann, 2011; Cruse, 1986): we can, for example, say $A$ Winesap is a kind of apple but not An apple is a kind of Winesap. Moreover, apple and pear are hyponyms of fruit, which is also a hyperonym of all hyponyms of apple and pear. This classification follows the distinction of (taxonomic) category levels in subordinate ('Winesap-level'), basic ('apple-level'), and superordinate ('fruit-level'), as proposed by Rosch (1978; see also Rosch \& Mervis, 1975; Rosch, Mervis, Gray, Johnson, \& Boyes-Braem, 1976). A higher level in the hierarchy corresponds to a higher level of inclusiveness and thus to a higher level of abstraction of the respective category (see Rosch, 1978).

We have now defined taxonomic categories. However, the actual question in this paper is how different taxonomic categories are understood. We define elements from different taxonomic categories as follows:

$\mathrm{Y}$ as well as the hyponyms on all subordinate levels of $\mathrm{Y}$ are part of a different taxonomic category compared to $Z$ as well as the hyponyms on all subordinate levels of $\mathrm{Z}$ if $\mathrm{Y}$ and $\mathrm{Z}$ do not have the same hyperonym $\mathrm{x}$.

One might argue that, for a superordinate level category TH I N GS IN THE W O RLD, apple and, for example, table would belong to the same taxonomic category. However, such a broad category is not useful as it has a very high level of inclusiveness/abstraction, and the properties of its members vary widely. As 
categorisation needs to be economical or useful in such a way that members having the same properties are summarised, whereas members having different properties are differentiated from each other (Rosch et al., 1976; see also Rosch, 1978), it seems useful to categorise apple and table in different categories.

\subsection{FOCUS IN ALTERNATIVE SEMANTICS}

The central aspect of Alternative Semantics (Rooth, 1985, 1992) is the distinction between two semantic values a focused element entails: an ordinary and a focus semantic value (Rooth, 1992). Rooth (1992, p. 76) illustrates this distinction with the examples presented in (2) and (3).

(2) (a) $[\text { Mary }]_{\mathrm{F}}$ likes Sue.

(b) Ordinary semantic value: $\llbracket\left[\mathrm{S}_{\mathrm{S}}[\text { Mary }]_{\mathrm{F}}\right.$ likes Sue $\left.]\right]^{\circ}=\{$ like (Mary, Sue $\left.)\right\}$

(c) Focus semantic value: $\llbracket\left[\mathrm{s}[\text { Mary }]_{\mathrm{F}}\right.$ likes Sue $\left.]\right]^{\mathrm{f}}=\{$ like $(\mathrm{x}$, Sue $) \mid \mathrm{x} \in E\}$, where $E$ is the domain of individuals

(3) (a) Mary likes $[\text { Sue }]_{F}$.

(b) Ordinary semantic value: $\llbracket\left[{ }_{\mathrm{s}}\right.$ Mary likes $\left.[\text { Sue }]_{\mathrm{F}}\right] \rrbracket^{\circ}=\{$ like (Mary, Sue $\left.)\right\}$

(c) Focus semantic value: $\llbracket\left[\mathrm{s}\right.$ Mary likes $\left.[\text { Sue }]_{\mathrm{F}}\right] \rrbracket^{\mathrm{f}}=\{$ like (Mary, y) $\mid \mathrm{y} \in E\}$, where $E$ is the domain of individuals

The ordinary semantic value of (2a) can be derived compositionally and it corresponds to the sentence's meaning that an individual called Mary likes an individual called Sue, as displayed in (2b). (3a) has the same ordinary semantic value, as displayed again in (3b). Simply put, the ordinary semantic value is the "usual meaning" (Gotzner, 2017, p. 12) of the sentence. It can be derived for every linguistic element, for example, a word, a phrase, or a sentence, containing a focused element or not. The focus semantic value, by contrast, is an "additional semantic value" (Rooth, 1992, p. 76) which is added in the presence of focus. It is defined as a set of propositions that is obtained by replacing the focused element in its sentential context by an element of the same semantic type (Rooth, 1985, 1992). Thus, in Alternative Semantics, the function of focus is formalised by the focus semantic value. Here, we consider the alternative set not as a set of alternative propositions, but rather as the set of elements that can replace the focused element in the given context while still forming a grammatically and semantically felicitous utterance. Thus, the alternative set of (2a), where the subject (i.e., Mary) is focused, is the set of elements corresponding to the variable $\mathrm{x}$ in $x$ likes Sue, as displayed in (2c), including all possible individuals who might like Sue. In contrast, if the object of the sentence (i.e., Sue) is focused, as in (3a), the alternative set is the set of elements corresponding to the variable y in Mary likes $y$, as displayed in (3c). Here, all possible individuals who Mary might like are included (Rooth, 1992; see also, e.g., Gotzner, 2017; Rooth, 1985). In Alternative Semantics, the focused element is itself an element of the alternative set. 
The focus semantic value (and thus the alternative set) changes depending on the location and scope of focus and it affects pragmatic inferences which arise from the sentence (Rooth, 1992). Bare prosodic focus can be interpreted exhaustively such that a listener of, for example, (3a) might think that Mary likes Sue but no other person. However, this exhaustive interpretation is not part of the semantic meaning of focus; instead, it is a cancellable pragmatic inference (Krifka, 2007).

Most relevant for the present study is the use of focus in corrective contexts, in which focus is most commonly marked by a nuclear $\mathrm{L}+\mathrm{H}^{*}$ pitch accent (Pierrehumbert \& Hirschberg, 1990; see also Grice \& Baumann, 2002). The fundamental frequency (f0) contour of the nuclear $\mathrm{L}+\mathrm{H}^{*}$ pitch accent is characterised by an initial low f0 and a following steep rise to a high target (see Grice, Ritter, Niemann, \& Roettger, 2017; see also Pierrehumbert, 1980). Further characteristics of $\mathrm{L}+\mathrm{H}^{*}$ are a late f0 peak and an accented syllable which sounds high (Grice \& Baumann, 2002; Grice et al., 2017). Furthermore, pitch accented elements are often associated with longer durations and greater intensities (e.g., Ladd, 2008).

According to Pierrehumbert and Hirschberg (1990), the $\mathrm{L}+\mathrm{H}^{*}$ pitch accent is associated with a contrastive (or corrective) meaning in English discourses and therefore is often denoted as 'contrastive accent' (e.g., in Braun \& Tagliapietra, 2010). This corresponds to the classification of pitch accents in German of Grice and Baumann (2002). ${ }^{1}$ In this study, we will investigate the alternative set evoked by a contrastive pitch accent, in accordance with previous studies that will be summarised in the following two sections.

\subsection{THE COGNITIVE RELEVANCE OF FOCUS ALTERNATIVE SETS}

One of the first psycholinguistic studies investigating the role of prosodic focus in evoking alternatives was by Braun and Tagliapietra (2010; see also Husband \& Ferreira, 2016). The study on Dutch found that alternatives to a contrastively focused element are more easily available in lexical decision tasks than in a control condition without contrastive focus, suggesting that alternatives become activated in a listener's mind during the processing of prosodic focus. In an eye-tracking study on German, Braun, Asano, and Dehé (2018) observed that activation of alternatives is confined to nuclear $\mathrm{L}+\mathrm{H}^{*}$ accents, whereas prenuclear $\mathrm{L}+\mathrm{H}^{*}$ accents and other (nuclear) focus accents like $\mathrm{H}^{*}+\mathrm{L}$ do not activate alternatives (but see Braun \& Biezma, 2019, for counter-evidence

\footnotetext{
1 There is an ongoing debate about whether other pitch accents, e.g., H*, also mark contrastively interpreted focus (see Watson, Tanenhaus, \& Gunlogson, 2008). Moreover, it is widely debated whether there is a clear one-to-one mapping between different pitch accents and specific pragmatic meanings at all (e.g., Grice et al., 2017).
} 


\section{J ÖRDENS ET AL.}

that prenuclear $\mathrm{L}+\mathrm{H}^{*}$ can also activate alternatives). Fraundorf, Watson, and Benjamin (2010; see also Fraundorf, Benjamin, \& Watson, 2013) showed in a study on English that focus also improves recognition memory for alternatives.

Spalek and Oganian (2019) investigated the neural processes underlying the representation of focus alternatives using fMRI. Differences in alternative status were reflected in brain areas that had previously been implicated in linguistic coherence processing (e.g., Ferstl \& von Cramon, 2001). Of particular interest here is the behavioural pilot study conducted by the authors. Since we will use their design, we will describe it in some detail: Participants listened to a sentence with contrastive pitch accent on either the subject or the object, as exemplified in (4) (taken from Spalek \& Oganian, 2019; original sentences were in German). Afterwards, they saw a written probe word and had to decide whether it had occurred in the previous sentence. This word was either a semantically related alternative to the focused element from the same taxonomic category (e.g., peaches to cherries, (4b)); not a possible alternative to the focused element but semantically related to the sentence's object (e.g., peaches to Carsten, (4a)); or unrelated (e.g., cows). All critical probes required a 'no'-response.

(4) (a) $[\mathrm{CARSten}]_{\mathrm{F}}$ has picked cherries from the tree.

(b) Carsten has picked $[\text { CHERries }]_{\mathrm{F}}$ from the tree.

Participants rejected unrelated probes faster than related ones. According to the authors, this is intuitively plausible because, when a sentence is about fruit, it is easier to decide that cows were not part of this sentence than that peaches were not part of it. Crucially, Spalek and Oganian (2019) found a reaction time difference between alternatives and non-alternatives: alternatives were rejected faster than non-alternatives, suggesting that the probes presented in the alternatives condition, in contrast to the probes presented in the non-alternatives condition, became activated as possible alternatives to the focused element and thus were easier to reject in the task. The experimental design employed by Spalek and Oganian revealed processing differences between focus alternatives and non-alternatives and thus allows, by implication, the drawing of conclusions about which elements are considered as part of the alternative set (and which are not).

\subsection{THE COMPOSITION OF FOCUS ALTERNATIVE SETS: FIRST EM P I R I C A L EVIDENCE}

Gotzner (2015) investigated whether focus alternatives need to be mutually exclusive, as suggested by Wagner (2006, 2012). While the theoretical account of Wagner focused on mutually exclusive adjectives (e.g., high end vs. cheap), Gotzner argued that sets of contextually restricted nouns are a comparable 
case. Often, restrictions imposed by the context concern co-hyponyms, for example, items bought at a fruit store (F R U I T ). Gotzner (2015) carried out an additional analysis on data from Gotzner, Wartenburger, and Spalek (2016). In this experiment, participants listened to a short discourse, as exemplified in (5) (taken from Gotzner, 2015, pp. 237f.; original sentences were in German). The critical sentence $(5 \mathrm{c})$ contained either the focus sensitive particle only and the focused prime word (i.e., jackets) or the focused prime word without a particle. After having listened to the spoken stimuli, participants performed a lexical decision task on a written target word which was either a mentioned alternative (e.g., shirts), an unmentioned alternative from the same taxonomic category (e.g., socks), or unrelated (e.g., lychees).

(5) (a) There are shirts, trousers, and jackets in the catalogue.

(b) I bet Matthias has bought shirts and trousers.

(c) No, he only / _ bought [jackets $]_{\mathrm{F}}$.

Gotzner and colleagues (2016) found that mentioned alternatives were recognised fastest, followed by unmentioned alternatives and then unrelated words. Moreover, responses were slower when only was present compared to the condition without a particle. Gotzner and colleagues concluded that mentioned as well as unmentioned alternatives become activated as members of an alternative set, and that focus particles cause interference, indicating stronger competition among these members.

In the post-hoc analysis, Gotzner (2015) looked more closely at the unrelated target words used by Gotzner and colleagues (2016). She argues that some of them were semantically and syntactically possible replacements for the focused element and therefore possible alternatives, although they were from a different taxonomic category than the focused element (e.g., lychees in (5)). She coded whether an unrelated target was a possible replacement for the focused element and included this factor in the post-hoc analysis. Unrelated targets that were not possible replacements for the focused element patterned with the original unrelated condition. Unrelated targets that were possible replacements for the focused element, however, patterned with the unmentioned alternatives. These results indicate that elements from different taxonomic categories can be part of an alternative set if they are possible replacements for the focused element. However, as this conclusion is based on the post-hoc analysis of an experiment that had not specifically been designed to test this, it is important to confirm these results.

Kim, Gunlogson, Tanenhaus, and Runner (2015; see also Kim, 2012; Kim, Gunlogson, Tanenhaus, \& Runner 2009) used eye-tracking to investigate how focus alternatives are generated during discourse processing, and how these alternatives are used to predict a focused element in a sentence containing a focus sensitive particle. They presented participants with short, spoken 


\section{J ÖRDENS ET AL.}

English discourses, for example, Neil has some pears and some apples. Alex only /_has some apples., and found that a focused element that had already been mentioned in the context (i.e., apples) was predicted better when it was preceded by the focus sensitive particle only than when no particle occurred. They also found that when the context introduced pears and oranges, participants were better at predicting the focused element apples than when elements from a different category (e.g., sandals and boots) had been introduced (see also Kim et al., 2009, esp. Figure 6). This indicates that listeners generate expectations about the focused element based on semantic relations to contextmentioned alternatives, suggesting that same-category members are more likely to be considered as alternatives. However, in another experiment, Kim and colleagues (2015) found that discourse context also plays a role in the composition of alternative sets: participants were faster at identifying the target referent of a focused element (e.g., a picture of hot dogs) in a biasing context (e.g., baseball game) than in a neutral context (e.g., supermarket). This indicates that listeners generate different expectations about the same focused element depending on the context.

Thus, discourse context seems to influence which elements are considered as focus alternatives. Elements from different taxonomic categories can be included in an alternative set when they are plausible alternatives in the given situation. This does not contradict the finding of Kim and colleagues (2015) that apples is predicted better when pears and oranges had been mentioned before: if the context introduces only elements from one category, it might be most plausible that an upcoming focused element also belongs to that category.

Further evidence for contextual influence on the composition of alternative sets comes from Fraundorf and colleagues (2013). They investigated the effects of focus on memory. Focus was realised by font emphasis in written English. They found that plausibility is a factor when encoding the alternative set: font emphasis improved a reader's memory for plausible alternatives but not for implausible ones. The authors conclude that readers encode a set of only those alternatives that are relevant in the situation described by the discourse. They further state that "the discourse can add alternatives from outside a semantic category” (2013, p. 214) if they are contextually plausible (see also Byram Washburn, 2013; Byram Washburn, Kaiser, \& Zubizarreta, 2011).

Language production research also suggests that unrelated elements from different taxonomic categories can be dynamically grouped together in a specific contextual setting. Abdel Rahman and Melinger (2011) found semantic interference for unrelated items from different taxonomic categories (e.g., coffee, knife, bucket, stool, creek; originally in German) in a semantic blocking paradigm when the items were preceded by a title word providing a common theme (e.g., fishing trip). The effect was similar to the one for taxonomically related items (e.g., stool, shelf, blackboard, mat, altar - F UR N I T U RE). Crucially, no 
interference was found for items from different taxonomic categories when no title had been presented, "leaving the thematic relation between the objects opaque” (2011, p. 156). Thus, non-taxonomic categories can be built dynamically during language processing by the information provided by the context even if the context is reduced to a title word (see also, e.g., Barsalou, 1982, 1983, 1985, 1991). Transferring this to focus alternative sets, we hypothesise that they are also dynamically built upon contextual information, making them a flexible construct that depends on the specific contextual situation.

\section{Experiment}

\subsection{AIMS AND PREDICTIONS}

We examine whether a focus alternative set can contain elements from different taxonomic categories, using a cross-modal priming paradigm with probe recognition (see Spalek \& Oganian, 2019). In this task, participants first listen to a sentence and are then presented with a written probe word for which they have to decide whether it had occurred in the preceding sentence. Probe recognition has been used extensively in research on recognition memory and goes back at least to the 1960s (see Sternberg, 1969). When used to investigate language comprehension, probe recognition is assumed to indicate "how accessible concepts are in the subjects' mental representations of a discourse" (Gernsbacher \& Jescheniak, 1995, p. 31; see also Glenberg, Meyer, \& Lindem, 1987). This task can thus give insights into the composition of an alternative set by measuring whether the potential alternative is indeed part of the listener's mental representation.

In our experiment, participants listened to a sentence containing a focus accented prime word and then saw a written probe word that either was a potential alternative to the focused element and related to the sentence (Rel_Alt), not a possible focus alternative but nonetheless related to the sentence (Rel_NoAlt), or unrelated (Unr). Crucially, and in contrast to Spalek and Oganian (2019), focused prime and probe belonged to different taxonomic categories. The probe was never present in the spoken sentence in the critical conditions, requiring a 'no'-response in all conditions.

Based on Spalek and Oganian (2019), we predict faster reaction times for unrelated probes than for related ones (Rel_Alt and Rel_NoAlt) because unrelated probes deviate strongly from the general content of the spoken sentence. In other words: there should be an inhibitory effect of relatedness because related probes are consistent with the sentence context and it should be more difficult to reject them as not having occurred. We further predict faster reaction times for potential focus alternatives (Rel_Alt) than for related words that are not alternatives (Rel_NoAlt) if, and only if, the words in the Rel_Alt condition are considered as part of the alternative set. By contrast, if elements 
JÖRDENS ET AL.

from different taxonomic categories are not considered as focus alternatives, we expect no significant reaction time difference between Rel_Alt and Rel_NoAlt.

\subsection{METHO D}

\subsubsection{Participants}

Thirty-nine native speakers of German ( 22 women, mean age 25.33 , sd $=4.67$ ) were recruited via LingEx, the participant pool of the Leibniz-Zentrum Allgemeine Sprachwissenschaft (ZAS), Berlin. All but one were right-handed. None of them reported any vision or hearing difficulties. Participants were paid seven euros in compensation.

\subsubsection{Materials}

2.2.2.1. Critical items Ninety sentences similar to (6) were created. Each sentence contained an initial subject noun phrase (a denotation of a person or a name), an object noun phrase, and another noun phrase, which was most commonly embedded in a prepositional phrase. Either the subject (i.e., Bauer, 'farmer' in (6)) or the object (i.e., Stroh, 'straw' in (6)) of the sentence was focus accented and served as prime word in the probe recognition task.

(6) Der Bauer hat Stroh in den Stall gebracht.

'The farmer has brought straw into the barn.'

Each prime sentence was paired with a written probe word in one of three critical conditions: the probe was either an alternative (Rel_Alt), not an alternative (Rel_NoAlt), or unrelated (Unr) to the focused prime (see Table 1).

T A B LE 1. Examples of the critical conditions (see 'Appendix B' for all experimental sentences and associated probe words)

\begin{tabular}{|c|c|c|c|}
\hline Condition & Spoken sentence & $\begin{array}{l}\text { Probe } \\
\text { word }\end{array}$ & $\begin{array}{l}\text { Required } \\
\text { response }\end{array}$ \\
\hline \multirow[t]{2}{*}{ Rel_Alt } & Der Bauer hat $[S T R O H]_{F}$ in den Stall gebracht. & Kühe & \multirow{2}{*}{ no } \\
\hline & 'The farmer has brought $[\text { STRAW }]_{\mathrm{F}}$ into the barn.' & 'cows' & \\
\hline \multirow[t]{2}{*}{ Rel_NoAlt } & Der $[B A U e r]_{F}$ hat Stroh in den Stall gebracht. & Kühe & \multirow{2}{*}{ no } \\
\hline & & & \\
\hline \multirow[t]{2}{*}{ Unr } & $\begin{array}{l}\text { Der Bauer hat }[S T R O H]_{F} \text { in den Stall gebracht. / Der } \\
\quad[\text { BAUer }]_{F} \text { hat Stroh in den Stall gebracht. }\end{array}$ & Aufzüge & \multirow[t]{2}{*}{ no } \\
\hline & $\begin{array}{l}\text { 'The farmer has brought }[\text { STRAW }]_{\mathrm{F}} \text { into the barn.' / } \\
\text { 'The }[\text { FARmer }]_{\mathrm{F}} \text { has brought straw into the barn.' }\end{array}$ & 'lifts’ & \\
\hline
\end{tabular}


More specifically, in the Rel_Alt condition, the probe was a plausible substitute for the focused prime. In this condition, focus accent was always on the object of the prime sentence (here: straw), making the probe cows a potential focus alternative (see Table 1). Crucially, prime and probe belonged to different taxonomic categories (i.e., straw - F E E D ; cows - A N I M A L S ). In the Rel_NoAlt condition, the same probe as in the Rel_Alt condition was presented. However, in this condition, focus accent was always on the subject of the sentence (here: farmer), and therefore the probe (cows) was not a possible alternative in the given context. In the Unr condition, the probe was neither related to the sentence context nor a contextually appropriate alternative to the focused prime (i.e., lifts, see Table 1). In this condition, the focus accent was either on the subject or on the object of the prime sentence.

The Unr condition was created by recombining prime sentences and probe words, thereby controlling for potential influences of word length or frequency on probe recognition times.

The prime words in the spoken prime sentences and the written probe words were matched on word length and frequency, which were extracted from the database dlexDB (Heister et al., 2011).

A pilot study using the online survey tool LimeSurvey (https://www. limesurvey.org/) was conducted to test whether related probes were indeed good substitutes for the prime (and unrelated probes were not): participants rated on a 5-point scale the grammaticality and meaningfulness of the sentences containing either the prime, the related probe, or the unrelated probe. In the final stimulus set, the related probe words were grammatically and meaningfully good substitutes for the prime words of the sentences (prime: mean grammaticality $=4.69$, sd $=0.19$, mean meaningfulness $=4.64, \mathrm{sd}=0.27$; related probe: mean grammaticality $=4.67, \mathrm{sd}=0.24$, mean meaningfulness $=$ 4.66 , sd $=0.26$ ), whereas the unrelated probe words were not meaningful substitutes and showed slightly reduced grammaticality ratings (mean grammaticality $=4.64, \mathrm{sd}=0.20$, mean meaningfulness $=1.91, \mathrm{sd}=0.53$ ).

In a second pilot study with LimeSurvey, participants rated the semantic relatedness of the related and the unrelated prime-probe pairs. Related word pairs were supposed to be unrelated in isolation because the prime and the related probe belonged to different taxonomic categories and only the sentence context made them related to each other. However, we expected related word pairs to be somewhat more related than 'truly' unrelated word pairs because these words often occur in same contexts. The results confirmed our expectations: related word pairs (from different taxonomic categories) were perceived as more related $($ mean $=2.17, \mathrm{sd}=0.74)$ than unrelated ones $($ mean $=1.43, \mathrm{sd}=0.45, t(89)=8.46$, $p<.0001)$. A control group of word pairs from the same taxonomic category $(\mathrm{n}=$ 15 ) was perceived as even more related (mean $=4.05$, sd $=0.26)$. In sum, the pilot studies confirmed that the probe words had been chosen appropriately. 
2.2.2.2. Filler items 125 filler items were created. As the response to all critical probe words was 'no' (see Table 1), one group of fillers required a 'yes'-response. Fillers should also ensure that participants listen attentively to the whole sentence. Therefore, different filler types were created in which all nominal parts of the sentences (i.e., subject, object, or sentence-final noun) were presented as probes. There were five different filler types (see Table 2). In all filler prime sentences, focus accent could be either on the subject or on the object (not illustrated in Table 2 for reasons of simplicity).

\subsubsection{Recordings Sentences were recorded in a sound-attenuated booth} using two Sennheiser microphones (ME 64), a two-channel microphone preamplifier (MA 3), and a Roland Edirol (E 09) solid state recorder $(44.1 \mathrm{kHz}$ sampling frequency, 16-bit resolution).

Sentences were embedded in question-answer contexts which triggered a contrastive focus on either the subject or the object of the sentence. The speaker reading the answers (i.e., the experimental prime sentences) was instructed to pronounce either the subject or the object with contrastive $\mathrm{L}+\mathrm{H}^{*}$ pitch accent, placing no other accents in the sentence. ${ }^{2}$ The answers were read by the first author of this study (a female native speaker of German, northern German / Lower Saxony accent). The preceding questions were spoken by a male native speaker of German who was a trained phonetician.

We measured duration, mean intensity, maximum and minimum pitch (f0), and the f0-excursion for subjects and objects (i.e., over the word) in both intonation conditions of the sentences (subject and object focus) ${ }^{3}$ with the software Praat (Boersma \& Weenink, 2018), using a script by Xu (2013). All acoustic measures for the object of the sentence were significantly higher in the object focus condition than in the subject focus condition (see Table 3): focused objects, compared to non-focused ones, had an increased duration and intensity as well as a higher pitch excursion. For the subject of the sentence, the results were reversed: all measures were significantly higher in the subject focus condition than in the object focus condition (see Table 4). Crucially, sentences with object focus and sentences with subject focus display distinct pitch profiles as shown in Figures 1 and 2.

2.2.2.4. Experimental lists Three stimulus lists were created using a Latin square design so that each list contained each of the 90 critical spoken sentences in only one of the three critical conditions. A given list contained 30 sentences per condition. The 125 fillers were added to each of the three lists, resulting in 215 trials. 20 fillers required 'no'-responses and 105 fillers required

\footnotetext{
2 See <https://tinyurl.com/NonCatFocAlt $>$ for the recordings.

3 Only critical items were included in the acoustic analysis.
} 
T A B LE 2. Examples for the five filler types

\begin{tabular}{|c|c|c|c|}
\hline $\begin{array}{l}\text { Filler type } \\
\text { (number of) }\end{array}$ & Spoken sentence & Probe word & $\begin{array}{l}\text { Required } \\
\text { response }\end{array}$ \\
\hline \multirow[t]{2}{*}{ Obj_yes (35) } & Robert hat die Kegel mit der Kugel verfehlt. & Kegel & \multirow{2}{*}{ yes } \\
\hline & 'Robert has missed the pins with the bowl.' & 'pins' & \\
\hline \multirow[t]{2}{*}{ Subj_yes (35) } & $\begin{array}{l}\text { Der Elektriker hat Kabel im Transporter } \\
\text { verstaut. }\end{array}$ & Elektriker & \multirow{2}{*}{ yes } \\
\hline & 'The electrician has put cables in the van.' & 'electrician’ & \\
\hline \multirow[t]{2}{*}{ Subj_no (10) } & $\begin{array}{l}\text { Hartmut hat Nüsse mit dem Nussknacker } \\
\text { geknackt. }\end{array}$ & Fritz & \multirow[t]{2}{*}{ no } \\
\hline & $\begin{array}{l}\text { 'Hartmut has cracked nuts with the } \\
\text { nutcracker.' }\end{array}$ & 'Fritz' & \\
\hline \multirow[t]{2}{*}{ PP_yes (35) } & $\begin{array}{l}\text { Rita hat die Bücher im Wohnzimmer } \\
\text { abgestaubt. }\end{array}$ & Wohnzimmer & \multirow[t]{2}{*}{ yes } \\
\hline & 'Rita has dusted the books in the living room.' & 'living room' & \\
\hline \multirow[t]{2}{*}{ PP_no (10) } & Der Maler hat die Farbe in den Flur gestellt. & Schlafzimmer & \multirow{2}{*}{ no } \\
\hline & 'The painter has put the paint in the hallway.' & 'bedroom' & \\
\hline
\end{tabular}

Note $. \mathrm{Obj}=$ Object; Subj $=$ Subject; $\mathrm{PP}=$ sentence-final noun .

TABLE 3. Acoustic measures for the sentence о В JЕ С $\mathrm{T}$ in subject focus (SF) and object focus $(\mathrm{OF})$ condition

\begin{tabular}{lllllllc}
\hline & & Mean & SD & Min & Max & $\boldsymbol{t}$ & $\boldsymbol{p}$ \\
\hline duration (in ms) & SF & 398.59 & 78.07 & 249 & 593 & & \\
& OF & 556.57 & 102.96 & 361 & 821 & & \\
intensity (in dB) & SF & 54.30 & 2.19 & 48.68 & 59.46 & & \\
& OF & 60.79 & 2.41 & 55.82 & 67.75 & & \\
max f0 (in Hz) & SF & 209.33 & 29.54 & 184 & 461 & & \\
& OF & 449.96 & 31.86 & 367 & 519 & & \\
min f0 (in Hz) & SF & 164.82 & 35.10 & 80 & 196 & & \\
& OF & 190.87 & 33.25 & 78 & 315 & & \\
& & & & & & 6.000 & \\
f0-excursion & SF & 4.81 & 5.04 & 0.45 & 29.67 & & \\
(in semitones) & OF & 15.65 & 2.81 & 8.05 & 27.33 & & \\
& & & & & & 20.30 & $<.00001$ \\
& & & & & & & \\
\hline
\end{tabular}


J ÖRDENS ET AL.

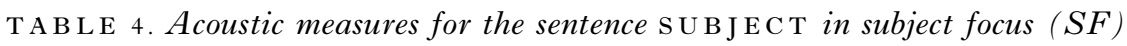
and object focus (OF) condition

\begin{tabular}{lllllllc}
\hline & & Mean & SD & Min & Max & $\boldsymbol{t}$ & $\boldsymbol{p}$ \\
\hline duration (in ms) & SF & 599.04 & 161.41 & 319 & 1234 & & \\
& OF & 440.76 & 134.67 & 224 & 1003 & & \\
intensity (in dB) & SF & 61.22 & 2.12 & 55.74 & 69.66 & -22.94 & $<.0001$ \\
& OF & 56.13 & 2.47 & 49.89 & 65.60 & & \\
max f0 (in Hz) & SF & 450.76 & 34.62 & 363 & 526 & & \\
& OF & 224.60 & 48.41 & 184 & 489 & & \\
min f0 (in Hz) & SF & 195.89 & 24.12 & 80 & 289 & & \\
& OF & 179.46 & 19.10 & 77 & 197 & & \\
& & & & & & -60.36 & \\
f0-excursion & SF & 14.56 & 2.25 & 6.66 & 21.29 & & \\
(in semitones) & OF & 3.90 & 3.36 & 0.37 & 19.38 & & \\
& & & & & & -26.32 & $<.00001$ \\
\hline
\end{tabular}

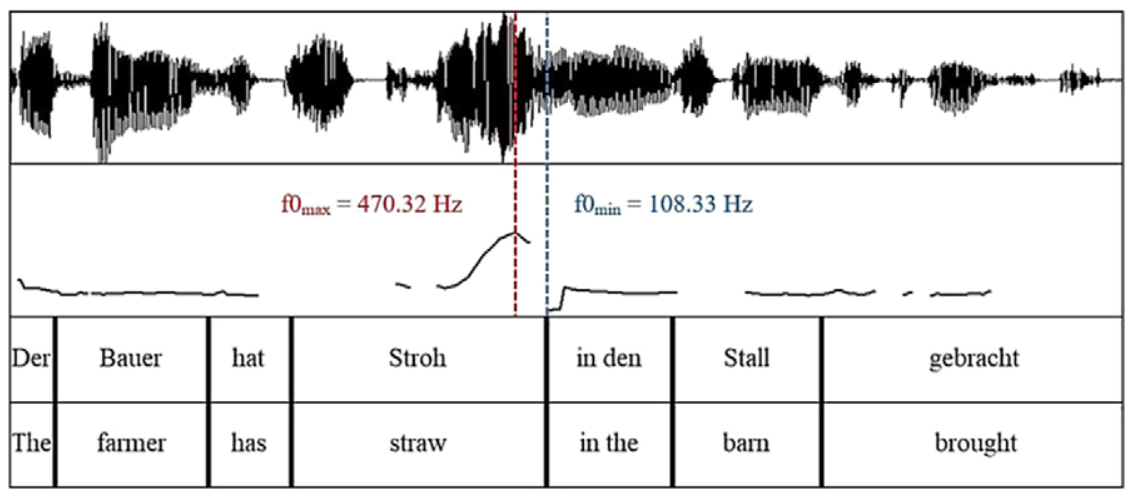

Fig. 1. Pitch contour (f0) for an example sentence in object focus condition (focus on the object Stroh, 'straw'), extracted from Praat (Boersma \& Weenink, 2018).

'yes'-responses (see Table 2). Since all 90 critical items required responding 'no' (see Table 1), there were 110 'no'- and 105 'yes'-responses overall.

A given list was split into five blocks. A second version of each list was created by changing the block order, resulting in six experimental lists.

For each participant, a given list was pseudo-randomised with the software Mix (van Casteren \& Davis, 2006), using the following constraints: (1) a critical condition (Rel_Alt, Rel_NoAlt, Unr) was only presented once in a row; (2) no more than three fillers were presented in a row; (3) no more than three sentences with the same focus accent were presented in a row; (4) the same 


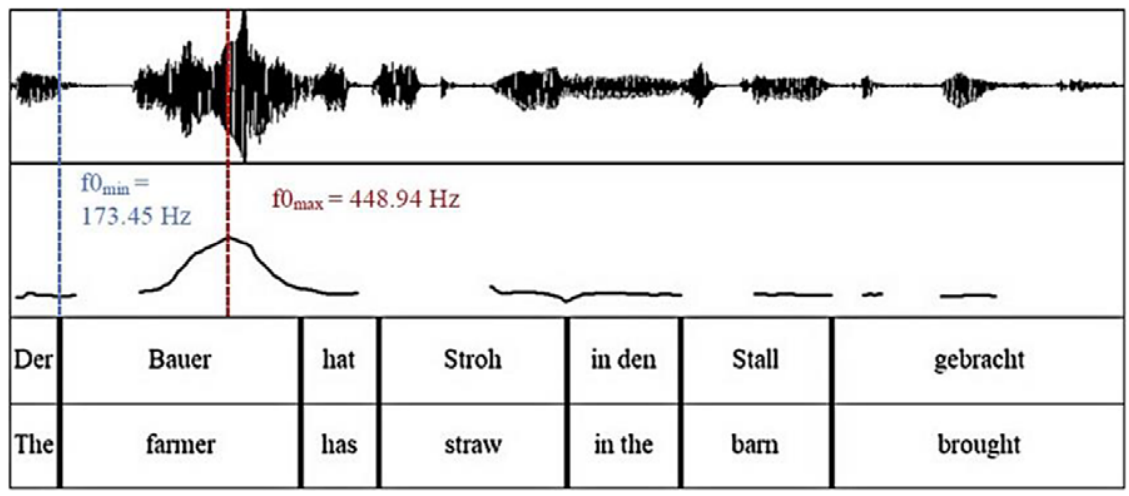

Fig. 2. Pitch contour (f0) for an example sentence in subject focus condition (focus on the subject Bauer, 'farmer'), extracted from Praat (Boersma \& Weenink, 2018).

response (yes/no) occurred no more than twice in a row; (5) a minimal distance of three between object prime words of the same taxonomic category; (6) a minimal distance of three between probe words of the same taxonomic category; and (7) a minimal distance of four between sentences with a similar thematic context.

\subsubsection{Procedure}

Participants signed an informed consent form and a data protection information form. They were tested individually in front of an 18-inch CRT-monitor (type ELSA), wearing a PC131 Sennheiser headset. Two external response buttons were used. Stimuli were presented with the Presentation software (version 16.5, Neurobehavioral Systems <https://www.neurobs.com/>).

The experiment started with written instructions on the screen. Participants were told that they would listen to a spoken sentence via headphones and, after a delay, a written word would appear on the screen. Their task was to decide via button press (yes/no) whether the word had occurred in the spoken sentence. Speed and accuracy of the responses were likewise emphasised. After the instructions, participants performed a practice session with twelve trials, including all trial types (critical and filler). Participants could adjust the volume during the practice session.

Each trial had the same basic structure: a fixation cross was presented in the centre of the screen while the auditory sentence was played via headphones. $4000 \mathrm{~ms}$ after the sentence, the probe word appeared on the screen and stayed until the participant responded. If there was no response within $5000 \mathrm{~ms}$, the trial counted as a miss and the participant received written feedback on the screen (i.e., Bitte schneller antworten! 'Please respond faster!'). Only in the 


\section{JÖRDENS ET AL.}

practice session did participants receive additional feedback for wrong responses (i.e., Falsch! 'Wrong!'). After each response, the next trial was initiated with an offset of 500 ms showing a blank screen. Between blocks, participants had a short break.

After the experiment, participants were asked for demographic information, including age, origin ('Bundesland'), field of study, handedness, and possible strategies used during the experiment. A testing session lasted about 45 minutes.

\subsection{DATA ANALYSIS AND RESULTS}

One participant was excluded from further analysis because the participant's number of errors $(n=15)$ deviated more than three standard deviations from the mean number of errors. The remaining 38 participants made 157 errors overall (1.92\% of all remaining observations). 132 errors occurred in filler trials and 25 in critical trials. Incorrect responses and filler trials were excluded from further analysis. One datapoint was excluded because the reaction time was $0 \mathrm{~ms}$, indicating an unintentional button press.

Outliers with raw reaction times deviating more than two standard deviations from a participant's condition mean $(n=158,4.65 \%$ of observations before exclusion) were excluded from further analysis.

The reaction times were $\log 10$-transformed and analysed with a linear mixed effects model using the R-packages lme4 (Bates, Mächler, Bolker, \& Walker, 2015) and lmerTest (Kuznetsova, Brockhoff, \& Christensen, 2017). The model included condition and centred trial as fixed effects as well as random effects for participants and probe words, and random slopes for condition on the participant and for condition on the probe word intercept. ${ }^{4}$ We used planned contrasts for the factor 'condition' with the first contrast comparing the two related conditions with the unrelated condition (Rel_Alt 1, Rel_NoAlt 1, Unr -2) and the second one comparing (potential) alternatives with nonalternatives (Rel_Alt-1, Rel_NoAlt 1, Unr 0). ${ }^{5}$ After having defined the linear mixed effects model, 78 further datapoints $(2.41 \%$ of observations before exclusion) were removed because their residuals were identified as outliers (see Baayen, 2008, pp. 256ff.). The mean reaction times are displayed in Figure 3.

\footnotetext{
${ }^{4}$ Spalek \& Oganian (2019) used a similar model to analyse their pilot data, allowing a direct comparison of their results to ours.

5 These contrasts are essentially the same as the Helmert-contrast built into R, with two changes: (1) the comparison of the mean of the related conditions to the unrelated condition is done first; and (2) we have changed the polarity, subtracting the unrelated (baseline) condition from the mean of the two related conditions, while the standard contrast does it the other way round.
} 


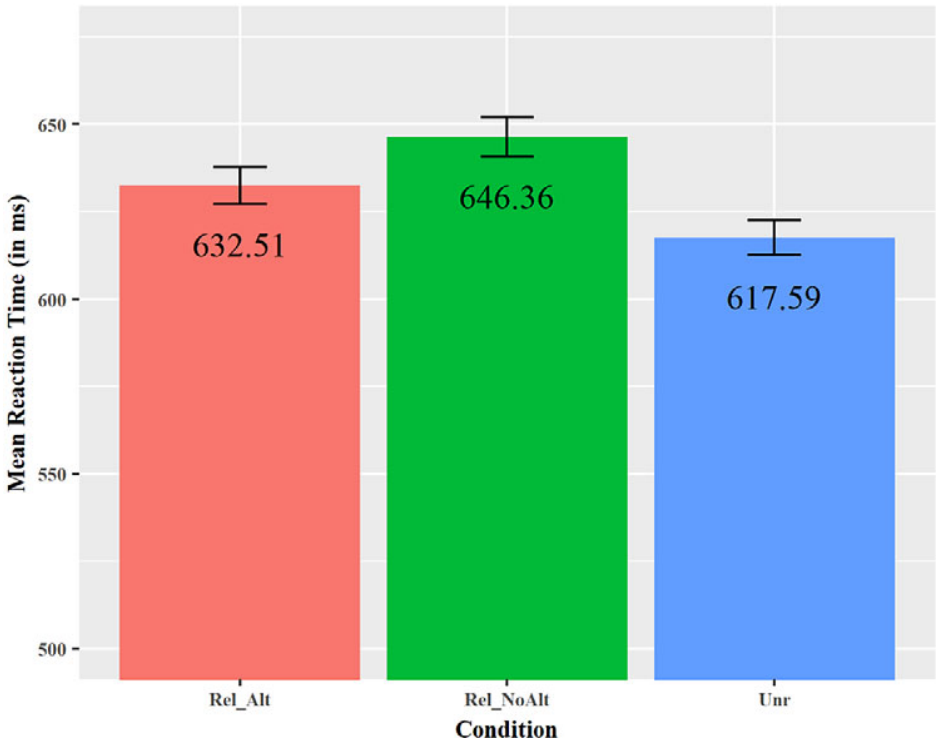

Fig. 3. Mean reaction times (in $\mathrm{ms}$ ) for the experimental conditions. Error bars represent standard error of the mean (SE).

T A B LE 5. Results of the linear mixed effects model for log10-transformed reaction times (model: $\log 10-R T \sim$ condition + centred trial $+(1+$ condition $\mid$ participant $)+(1+$ condition $\mid$ probe word $))$

\begin{tabular}{lrrrc}
\hline & Estimate & \multicolumn{1}{c}{ SE } & \multicolumn{1}{c}{$\boldsymbol{t}$} & \multicolumn{1}{c}{$\boldsymbol{p}$} \\
\hline $\begin{array}{l}\text { Intercept } \\
\text { Mean Related vs. Unrelated } \\
\quad \text { Relatedness Effect) }\end{array}$ & 0.00434 & 0.001295 & 215.42 & $<.0001$ \\
$\begin{array}{l}\text { Rel_Alt vs. Rel_NoAlt } \\
\quad \text { Alternative Effect) }\end{array}$ & 0.004072 & 0.001877 & 2.17 & $<.05$ \\
\begin{tabular}{l} 
Trial (centred) \\
\hline
\end{tabular} & -0.000149 & 0.00002 & -7.60 & $<.0001$ \\
\hline
\end{tabular}

The results of the linear mixed effects model (Table 5) show that unrelated probes (Unr) were rejected significantly faster than related ones (i.e., Rel_Alt and Rel_NoAlt combined) $(t=3.66, p<.0001)$. This was the expected inhibitory effect of relatedness: unrelated words are not consistent with the sentence context and can therefore be easily rejected.

Moreover, probe words in the Rel_Alt condition were rejected significantly faster than those in the Rel_NoAlt condition $(t=2.17, p<.05)$. Thus, participants identified elements that were possible substitutes for the focused element but that belonged to a different taxonomic category significantly faster 
JÖRDENS ET AL.

TABLE 6. Results of the post-hoc analysis: estimated marginal means of condition

\begin{tabular}{lllcc}
\hline Contrast & Estimate & SE & $\boldsymbol{t}$ & $\boldsymbol{p}$ \\
\hline Rel_Alt - Unr & 0.00922 & 0.00456 & 2.02 & .0875 \\
Rel_NoAlt - Unr & 0.01899 & 0.00472 & 4.02 & $<.001$ \\
\hline
\end{tabular}

as not having occurred in the previously heard sentence than elements that were not possible substitutes for the focused element. Finally, there was a significant effect for trial, showing that participants became faster during the course of the experiment.

A post-hoc analysis (Table 6) using the R-package emmeans (Lenth, 2019) was run to further investigate the differences between the experimental conditions, using the multivariate- $t$ adjustment for $p$-values. The analysis revealed that probe words in the Unr condition were rejected significantly faster than those in the Rel_NoAlt condition $(t=4.02, p<.001)$. However, reaction times in the Unr condition were not significantly faster than reaction times in the Rel_Alt condition $(t=2.02, p>.05)$. This replicates the results by Spalek and Oganian (2019), which we will discuss in the following section.

\section{Discussion}

The present study investigated whether elements from a different taxonomic category than the focused element become activated as focus alternatives in a listener's mind when a sentence containing this focused element is processed. We used a cross-modal priming paradigm with probe recognition. Prime sentences contained a focus accented word and were followed by a written probe word which was not present in the sentence, but which was either a potential focus alternative from a different taxonomic category (Rel_Alt), not a possible focus alternative but contextually related to the sentence (Rel_NoAlt), or unrelated (Unr). Based on a previous study by Spalek and Oganian (2019), we predicted an inhibitory effect of relatedness (i.e., Unr $<$ Rel_Alt and Rel_NoAlt) and a facilitatory effect of alternative status (i.e., Rel_Alt $<$ Rel_NoAlt).

The results were congruent with these predictions, providing evidence that an alternative set can contain elements from different taxonomic categories. Thus, the composition of an alternative set is not solely based on semantic relatedness. Instead, context plays a crucial role, as already suggested by Kim and colleagues (2015) and Fraundorf and colleagues (2013): focus alternatives need to be plausible or relevant, given what we know about the situation described by the sentence context. Therefore, what is considered as a possible 
focus alternative depends also on situation or world knowledge. Various studies on language processing more generally (e.g., Abdel Rahman \& Melinger, 2011; Barsalou, 1982, 1983, 1985, 1991) support this assumption: elements from different taxonomic categories can be dynamically grouped together when a given context establishes a plausible relation between these otherwise (semantically) unrelated elements. Interestingly, the relation between the focused element and its alternatives from another taxonomic category was not made explicit in the current experiment, as the alternatives were not mentioned in the context. This suggests that the sentence context was sufficient to establish a relation between the focused element and its alternatives. These findings show a parallel to the underlying principle of Latent Semantic Analyses (LSA), assuming that semantic relatedness between two words is defined by their occurrence in the same (con)text, which is also known as distributional hypothesis (see, e.g., Deerwester, Dumais, Furnas, Landauer, \& Harshman, 1990; Harris, 1954).

The results also revealed the expected inhibitory effect of relatedness. A post-hoc analysis showed that this effect was only present for related words that were not possible alternatives to the focused element. Between related words that were possible alternatives, belonging to another taxonomic category than the focused element, and unrelated words, no significant difference was found. This is congruent with the results of the companion study by Spalek and Oganian (2019) for same-category alternatives: in their study, inhibition was also only found for words that were not possible focus alternatives. The authors traced this result back to a facilitatory effect for focus alternatives that compensates the inhibitory effect of relatedness. The similarity of the results of the two studies suggests that focus alternatives from a different taxonomic category than the focused element become facilitated as focus alternatives in the same way as alternatives from the same category as the focused element because the inhibitory effect of relatedness could be compensated for in both cases. This indicates that same-category elements are not 'better' alternatives than different-category elements. Contextually related elements from another taxonomic category are equally 'good' focus alternatives even if they lack the semantic similarity to the focused element. In other words: there is no difference in alternative status of elements from different taxonomic categories and elements from the same taxonomic category as the focused element. This again emphasises the importance of contextual aspects besides semantic considerations when determining a proper focus alternative (see also Rooth, 1992, and $\mathrm{Xu}, \mathrm{Qu}$, Shen, \& Li, 2019, whose results indicated a co-activation of both contextual and semantic relations to a spoken Chinese word during language processing).

In order to further investigate this, we analysed the data from the present study together with the data from Spalek and Oganian (2019), adding 


\section{J ÖRDENS ET AL.}

'taxonomy' as a between-participants factor (see 'Appendix A' for details). While there was a main effect of taxonomy such that probe words from the same taxonomic category were rejected more slowly overall, taxonomy did not interact with the focus condition, supporting our assumption that the effect is not caused by semantic category membership as such but rather by the goodness of contextual fit of the focus alternative, a measure that is often confounded with category membership.

One limitation of the present study is that we did not use a fully crossed design, and therefore alternative status was confounded with focus position. Given that the sentence subject was always a person, it would not have been possible to find a sufficient number of probe words that were nontaxonomically related to it. Adding animals or objects causing an event as subjects (e.g., The avalanche killed the skiers on the slope.) would have meant a strong deviation from the sentence type used by Spalek and Oganian (2019), and we explicitly wanted to compare the two studies. Additionally, fully crossing focus position and alternative status would have doubled the study's length, causing fatigue and inattention. Thus, we cannot claim that our results generalise over linear position and syntactic and thematic roles. However, some previous findings suggest that such a generalisation is possible: Gotzner and Spalek (2019) showed that, after a certain amount of time, alternatives (compared to non-alternatives) remain active for a long time period after listening to a focused element. This alleviates concerns about the linear position of focus, with subject focus (in Rel_NoAlt) always occurring earlier than object focus (in Rel_Alt). Moreover, there is evidence that contrastively focused subjects do activate alternatives in a similar way as contrastively focused objects do (e.g., Braun et al., 2018; Braun \& Biezma, 2019).

From a theoretical point of view, the present study provides evidence for a permissive account of focus alternative sets (see Rooth, 1985, 1992; see Katzir, 2013, who introduced the term 'permissive'): various possible substitutes for the focused element, including elements from different taxonomic categories, are considered as part of the alternative set as long as they are contextually appropriate (see also Ndao \& Spalek, 2019). These results confirm Gotzner (2015).

In conclusion, the present study provides evidence that elements from different taxonomic categories can belong to an alternative set. This supports the assumption that the composition of focus alternative sets is not based only on semantic relations, but that contextual relations are likewise important: if a possible substitute for the focused element is plausible in the given context, it is a potential alternative. The findings provide further evidence that categorical relations are not exclusively relevant in language processing - words that are not in a categorical relation can be dynamically grouped and processed together as a coherent unit based on contextual information. 


\section{R E F E R E N C E S}

Abdel Rahman, R. \& Melinger, A. (2011). The dynamic microstructure of speech production: semantic interference built on the fly. Fournal of Experimental Psychology: Learning, Memory, and Cognition 37(1), 149-161.

Baayen, R. H. (2008). Analyzing linguistic data: a practical introduction to statistics using $R$. Cambridge: Cambridge University Press.

Barsalou, L. W. (1982). Context-independent and context-dependent information in concepts. Memory $\xi^{\circ}$ Cognition 10(1), 82-93.

Barsalou, L. W. (1983). Ad hoc categories. Memory $\Xi^{\circ}$ Cognition 11(3), 211-227.

Barsalou, L. W. (1985). Ideals, central tendency, and frequency of instantiation as determinants of graded structure in categories. Fournal of Experimental Psychology: Learning, Memory, and Cognition 11(4), 629-654.

Barsalou, L. W. (1991). Deriving categories to achieve goals. In G. H. Bower (ed.), The psychology of learning and motivation: advances in research and theory (pp. 1-64). San Diego / New York / Boston / London / Sydney / Tokyo / Toronto: Academic Press.

Barsalou, L. W. (2010). Ad hoc categories. In P. C. Hogan (ed.), The Cambridge encyclopedia of the language sciences (pp. 86-87). New York: Cambridge University Press.

Bates, D., Mächler, M., Bolker, B. M. \& Walker, S. C. (2015). Fitting linear mixed-effects models using lme4. Fournal of Statistical Software 67, 1-48.

Boersma, P. \& Weenink, D. (2018). Praat: doing phonetics by computer [Computer program]. Version 6.0.37, retrieved from http://www.praat.org/ (last accessed 14 March 2018).

Braun, B., Asano, Y. \& Dehé, N. (2018). When (not) to look for contrastive alternatives: the role of pitch accent type and additive particles. Language and Speech 62(4), 751-778.

Braun, B. \& Biezma, M. (2019). Prenuclear L*+H activates alternatives for the accented word. Frontiers in Psychology 10, e01993.

Braun, B. \& Tagliapietra, L. (2010). The role of contrastive intonation contours in the retrieval of contextual alternatives. Language and Cognitive Processes 25(7/9), 1024-1043.

Byram Washburn, M. (2013). Narrowing the focus: experimental studies on exhaustivity and contrast. Unpublished doctoral dissertation, University of Southern California. Online <http://digitallibrary.usc.edu/cdm/ref/collection/p15799coll3/id/295814>.

Byram Washburn, M., Kaiser, E. \& Zubizarreta, M. L. (2011). Focus facilitation and nonassociative sets. In R. Arstein, M. Core, D. DeVault, K. Georgila, E. Kaiser \& A. Stent (eds), Proceedings of the 15th Workshop on the Semantics and Pragmatics of Dialogue (pp. 94-102). Los Angeles. Online <https://projects.ict.usc.edu/nld/semdial2011/semdial2011-proceedings.pdf>.

Büring, D. (2016). Intonation and meaning. Oxford: Oxford University Press.

Cann, R. (2011). Sense relations. In C. Maienborn, K. von Heusinger \& P. Portner (eds), Semantics: an international handbook of natural language meaning (Vol. 1, pp. 456-479). Berlin / Boston: de Gruyter.

Cruse, D. A. (1986). Lexical semantics. Cambridge / London / New York / New Rochelle / Melbourne / Sydney: Cambridge University Press.

Deerwester, S., Dumais, S. T., Furnas, G. W., Landauer, T. K. \& Harshman, R. (1990). Indexing by latent semantic analysis. Fournal of the American Society for Information Science 41(6), 391-407.

Ferstl, E. C. \& von Cramon, D. Y. (2001). The role of coherence and cohesion in text comprehension: an event-related fMRI study. Cognitive Brain Research 11(3), 325-340.

Fraundorf, S. H., Benjamin, A. S. \& Watson, D. G. (2013). What happened (and what did not): discourse constraints on encoding of plausible alternatives. Fournal of Memory and Language 69(3), 196-227.

Fraundorf, S. H., Watson, D. G. \& Benjamin, A. S. (2010). Recognition memory reveals just how CONTRASTIVE contrastive accenting really is. Fournal of Memory and Language 63 (3), 367-386.

Gernsbacher, M. A. \& Jescheniak, J. D. (1995). Cataphoric devices in spoken discourse. Cognitive Psychology 29(1), 24-58.

Glenberg, A., Meyer, M. \& Lindem, K. (1987). Mental models contribute to foregrounding during text comprehension. Fournal of Memory and Language 26(1), 69-83. 


\section{JÖRDENS ET AL.}

Gotzner, N. (2015). What's included in the set of alternatives? Psycholinguistic evidence for a permissive view. In E. Csipak \& H. Zeijlstra (eds), Proceedings of Sinn und Bedeutung 19 (pp. 232-247). Göttingen. Online <https://semanticsarchive.net/Archive/TV1N2I2Z/ sub19proc.pdf>.

Gotzner, N. (2017). Alternative sets in language processing: how focus alternatives are represented in the mind. Cham: Palgrave Macmillan.

Gotzner, N. \& Spalek, K. (2019). The life and times of focus alternatives: tracing the activation of alternatives to a focused constituent in language comprehension. Language and Linguistics Compass 13(2), e12310.

Gotzner, N., Wartenburger, I. \& Spalek, K. (2016). The impact of focus particles on the recognition and rejection of contrastive alternatives. Language and Cognition 8(1), 59-95.

Grice, M. \& Baumann, S. (2002). Deutsche Intonation und GToBI. Linguistische Berichte 191, 267-298.

Grice, M., Ritter, S., Niemann, H. \& Roettger, T. B. (2017). Integrating the discreteness and continuity of intonational categories. Fournal of Phonetics 64, 90-107.

Harris, Z. S. (1954). Distributional structure. Word 10(2/3), 146-162.

Heister, J., Würzner, K.-M., Bubenzer, J., Pohl, E., Hanneforth, T., Geyken, A. \& Kliegl, R. (2011). dlexDB - eine lexikalische Datenbank für die psychologische und linguistische Forschung. Psychologische Rundschau 62, 10-20.

Husband, E. M. \& Ferreira, F. (2016). The role of selection in the comprehension of focus alternatives. Language, Cognition and Neuroscience 31(2), 217-235.

Katzir, R. (2013). A note on contrast. Natural Language Semantics 21(4), 333-343.

Kim, C. S. (2012). Generating alternatives: interpreting focus in discourse. Unpublished doctoral dissertation, University of Rochester. Online <https://urresearch.rochester.edu/ institutionalPublicationPublicView.action? institutionalItemId $=24363 \&$ versionNumber $=1>$.

Kim, C. S., Gunlogson, C., Tanenhaus, M. K. \& Runner, J. T. (2009). Focus alternatives and contextual domain restriction: a visual world eye-tracking study on the interpretation of 'only'. In A. Riester \& T. Solstad (eds), Proceedings of Sinn und Bedeutung 13 (pp. 261-274). Stuttgart. Online <https://semanticsarchive.net/Archive/DhhOTI2Z/sub13proc.pdf>.

Kim, C. S., Gunlogson, C., Tanenhaus, M. K. \& Runner, J. T. (2015). Context-driven expectations about focus alternatives. Cognition 139, 28-49.

Krifka, M. (2007). Basic notions of information structure. In C. Fery, G. Fanselow \& M. Krifka (eds), The notions of information structure: interdisciplinary studies on information structure (Vol. 6, pp. 13-56). Potsdam: Universitätsverlag.

Kuznetsova, A., Brockhoff, P. B. \& Christensen, R. H. B. (2017). lmer'Test Package: Tests in Linear Mixed Effects Models. Fournal of Statistical Software 82(13), 1-26.

Ladd, D. R. (2008). Intonational phonology (2nd edn). Cambridge / New York / Melbourne / Madrid / Cape Town / Singapore / São Paulo / Delhi: Cambridge University Press.

Lenth, R. (2019). emmeans: estimated marginal means, aka least-squares means. R package version 1.4.1. Online <https://CRAN.R-project.org/package $=$ emmeans $>$.

Löbner, S. (2013). Understanding semantics (2nd edn). London / New York: Routledge.

Murphy, G. L. (2010). What are categories and concepts? In D. Mareschal, P. C. Quinn, \& S. E. G. Lea (eds), The making of human concepts (pp. 11-28). Oxford / New York: Oxford University Press.

Ndao, A.-L. \& Spalek, K. (2019). What's the alternative? Experimental research on the extent of focus alternative sets. In A. Gattnar, R. Hörnig, M. Störzer \& S. Featherston (eds), Proceedings of Linguistic Evidence 2018: Experimental Data Drives Linguistic Theory (pp. 32-44). Tübingen. Online <https://publikationen.uni-tuebingen.de/xmlui/handle/10900/87132>.

Pierrehumbert, J. B. (1980). The phonology and phonetics of English intonation. Unpublished doctoral dissertation, Massachusetts Institute of Technology. Online $<$ https://dspace.mit. edu/handle/1721.1/16065>.

Pierrehumbert, J. B. \& Hirschberg, J. (1990). The meaning of intonational contours in the interpretation of discourse. In P. Cohen \& M. Pollack (eds), Intentions in communication (pp. 271-311). Cambridge, MA: MIT Press.

Rooth, M. (1985). Association with focus. Unpublished doctoral dissertation, University of Massachusetts. Online <https://scholarworks.umass.edu/dissertations/AAI8509599/>. 
Rooth, M. (1992). A theory of focus interpretation. Natural Language Semantics 1(1), 75-116.

Rosch, E. (1978). Principles of categorization. In E. Rosch \& B. B. Lloyd (eds), Cognition and categorization (pp. 27-48). Hillsdale, NJ: Lawrence Erlbaum Associates.

Rosch, E. \& Mervis, C. B. (1975). Family resemblances: studies in the internal structure of categories. Cognitive Psychology 7(4), 573-605.

Rosch, E., Mervis, C. B., Gray, W. D., Johnson, D. M. \& Boyes-Braem, P. (1976). Basic objects in natural categories. Cognitive Psychology 8(3), 382-439.

Spalek, K. \& Oganian, Y. (2019). The neurocognitive signature of focus alternatives. Brain and Language 194, 98-108.

Sternberg, S. (1969). Memory-scanning: mental processes revealed by reaction-time experiments. American Scientist 57(4), 421-457.

van Casteren, M. \& Davis, M. H. (2006). Mix, a program for pseudorandomization. Behavior Research Methods 38(4), 584-589.

Wagner, M. (2006). Givenness and locality. In M. Gibson \& J. Howell (eds), Proceedings of SALT 16 (pp. 295-312). Ithaca: CLC Publications.

Wagner, M. (2012). Focus and givenness: a unified approach. In I. Ku囚erová \& A. Neeleman (eds), Contrasts and positions in information structure (pp. 102-148). Cambridge: Cambridge University Press.

Watson, D. G., Tanenhaus, M. K. \& Gunlogson, C. A. (2008). Interpreting pitch accents in online comprehension: $\mathrm{H}^{*}$ vs. $L+H^{*}$. Cognitive Science 32(7), 1232-1244.

Xu, P., Qu, Q., Shen, W. \& Li, X. (2019). Co-activation of taxonomic and thematic relations in spoken word comprehension: evidence from eye movements. Frontiers in Psychology 10, e00964.

Xu, Y. (2013). ProsodyPro - a tool for large-scale systematic prosody analysis. In B. Bigi \& D. Hirst (eds), Proceedings of Tools and Resources for the Analysis of Speech Prosody (TRASP 2013) (pp. 7-10). Aix-en-Provence. Online <http://www.homepages.ucl.ac.uk/ uclyyix/ yispapers/Xu_TRASP2013.pdf>.

\section{Appendix A}

We analysed the data from the present study together with the data from Spalek and Oganian (2019), adding 'taxonomy' as a between-participants factor (for the present study, the value for this factor was 'no-tax', while for Spalek and Oganian, it was 'tax'). We modelled the data with main effects for condition (contrast 1 comparing the mean of both related conditions to the unrelated condition and contrast 2 comparing the Rel_Alt to the Rel_NoAlt condition) and centred trial, random effects for participants and items, and random slopes for condition on the participant and for condition on the item intercept. We used the lmer optimiser-function 'bobyqa' from the R-package lme4 (Bates et al., 2015). A model with a more complicated random effects structure including random slopes for centred trial on the participant intercept nevertheless failed to converge. We then added (1) a main effect for taxonomy and (2) an interaction of condition by taxonomy. While the addition of the main effect significantly improved the model fit $\left(\chi^{2}=14.07, p<.001\right)$, changing the main effect of taxonomy to an interaction of condition by taxonomy did not further improve model fit $\left(\chi^{2}=0.38, p=.83\right)$. The final model revealed a significant effect of relatedness such that the mean of the related conditions was significantly slower than the unrelated condition $(\mathrm{B}=0.0043, t=4.63, p<$ $.001)$, a significant effect of alternative status such that reaction times in Rel_NoAlt were slower than those in Rel_Alt $(\mathrm{B}=0.00535, t=3.34$, 


\section{J ÖRDENS ET AL.}

$p<.01$ ), a significant main effect of taxonomy such that items from the same taxonomic category (i.e., items from Spalek \& Oganian, 2019) were responded to more slowly than items in the present study $(\mathrm{B}=0.0903, t=4.08, p<.001)$. Finally, the effect of centred trial was significant: participants became faster during the experiment(s) $(\mathrm{B}=-0.000324, t=-8.08, p<.001)$.

\section{Appendix B}

List of all critical items used in the probe recognition experiment.

\section{Prime sentence}

Der Bauer hat Stroh in den Stall gebracht.

Der Techniker hat die Computer in der Universität gewartet.

Der Trauzeuge hat die Ringe im Auto vergessen.

Detlef hat Drogen auf dem Schwarzmarkt verkauft.

Der Chemiker hat die Trichter für das Labor nachbestellt.

Peter hat den Unfall vor seiner Frau verheimlicht.

Der Ritter hat sein Pferd auf dem Turnierplatz vergessen.

Thore hat die Möwen im Hafen fotografiert.

Der Pirat hat die Perlen in seiner Truhe bestaunt.

Emma hat ihren Schlüssel in der Handtasche gesucht.

Der Lehrer hat die Aufsätze in das Fach gelegt.

Der Meeresbiologe hat Plastik in den Weltmeeren untersucht.

Die Urlauberin hat einen Roman in den Koffer gepackt.

Lisa hat die Stühle für ihren Freund gestrichen.

Der Weihnachtsmann hat die Rentiere zum Schlitten gebracht.

Der Archäologe hat Keile in der Höhle gefunden.

Der Gärtner hat Dünger im Schuppen aufbewahrt.

Der Scheich hat Kamele in der Wüste gesichtet.

Der Sultan hat sich die Feigen auf dem Basar präsentieren lassen.

Der Schüler hat seine Brote zu Hause vergessen.

Der Angler hat Haken aus der Dose genommen.

Birte hat die Hosen in Kartons verpackt.

Der Reiter hat den Sattel nach dem Ausritt abgenommen.

Karin hat einen Sekt für das Picknick besorgt.

Der Florist hat Töpfe vor dem Geschäft drapiert.

Die Putzfrau hat das Parkett vor der Veranstaltung poliert.

Otto hat die Lampen im Baumarkt gesucht.

Jana hat Taschen aus Italien verschenkt.

Der Taucher hat seine Kamera im Meer verloren.

\begin{tabular}{ll}
$\begin{array}{l}\text { Related probe } \\
\text { word }\end{array}$ & \multicolumn{1}{c}{$\begin{array}{c}\text { Unrelated } \\
\text { probe wo }\end{array}$} \\
$\begin{array}{l}\text { Kühe } \\
\text { Aufzüge }\end{array}$ & $\begin{array}{l}\text { Aufzüge } \\
\text { Kühe }\end{array}$ \\
Torte & $\begin{array}{l}\text { Gewehre } \\
\text { Gewehre }\end{array}$ \\
Kittel & Affäre \\
Affäre & Kittel \\
Lanze & Boote \\
& \\
Boote & Lanze \\
Säbel & Ausweis \\
Ausweis & Säbel \\
Kreide & Fische \\
Fische & Kreide \\
& \\
Kleider & Wände \\
Wände & Kleider \\
Geschenke & Skelette \\
Skelette & Geschenke \\
Spaten & Oasen \\
Oasen & Spaten \\
Teppiche & Fahrkarte \\
& Teppiche \\
Fahrkarte & Gläser \\
Würmer & Würmer \\
Gläser & Korb \\
Helm & Helm \\
Korb & Besteck \\
Rosen & Rosen \\
Besteck & Oliven \\
Nägel & Nägel \\
Oliven & Tassen \\
Flossen & \\
&
\end{tabular}




\section{Continued}

\section{Prime sentence}

\section{Related probe}

word

Martin hat Brötchen auf den Frühstückstisch gestellt.

Der Zauberer hat seine Tauben für den Trick benötigt.

Der Astronaut hat die Rakete von der Raumstation aus beobachtet.

Das Baby hat die Flasche aus dem Kinderwagen geworfen.

Die Hexe hat ihre Kessel im Häuschen umgestellt.

Der Erstklässler hat Stifte in seiner Schultüte gefunden.

Rosi hat die Terrassa im Frühjahr geputzt.

Berta hat Stoffe zur Bastelstunde mitgebracht.

Armin hat Verwandte auf seiner Reise besucht.

Marvin hat die Laternen auf dem Herbstfest vermisst.

Der Soldat hat die Panzer für den Einsatz kontrolliert.

Der König hat die Diener in den Saal bringen lassen.

Der Forscher hat Insekten unter dem Mikroskop untersucht.

Die Tante hat Kuchen zum Geburtstag mitgebracht.

Jürgen hat Schilf in seinem Teich vermisst.

Lukas hat Flüge für die Europatour gebucht.

Lena hat ihre Haare in der Wanne gewaschen.

Katja hat Sterne am Himmel beobachtet.

Timo hat Konserven im Keller gelagert.

Maria hat ihre Zähne vor dem Treffen geputzt.

Holger hat Kerzen auf der Badewanne verteilt.

Anna hat Tickets im Kino gekauft.

Der Dieb hat Urkunden aus dem Tresor geklaut.

Karsten hat den Schlauch aus dem Beet entfernt.

Moritz hat den Zaun bei seinen Eltern repariert.

Elke hat ihre Kette zur Reparatur gebracht.

Der Koch hat das Messer in der Spüle gereinigt.

Anton hat Trikots von der Mannschaft signieren lassen.

Der Apotheker hat die Belege nach Feierabend sortiert.

Fenja hat die Schale für den Teig benötigt.

Lara hat ihre Puppe auf dem Spielplatz verloren.

Olga hat Sand in das Terrarium gegeben.

Der Hausmeister hat die Mieter am Tor abgeholt.

Philipp hat Holz im Wald gesammelt.

Der Friseur hat Bürsten für den Salon bestellt.

Sandra hat Hüte aus Papier gefaltet.

Nina hat Teller über die Theke gereicht.

Die Sekretärin hat Ordner auf den Schreibtisch gestellt.

Die Polizistin hat Betrüger in der Datenbank überprüft.

Dana hat Lianen im Regenwald gesehen.

Ludwig hat Socken ins Krankenhaus mitgebracht.

Busch

$\begin{array}{ll}\text { Tassen } & \text { Flossen } \\ \text { Münzen } & \text { Venus }\end{array}$

Venus

Münzen

Rassel

Besen

Besen

Rassel

Bonbons

Schränke

Schränke

Bonbons

Obst

Konzerte

Konzerte

Obst

Kürbisse

Uniform

Thron

Uniform

Kürbisse

Fasern

Fasern

Thron

Ballons

Frösche

Hotels

Blusen

Vögel

Wein

Schuhe

Blüten

Getränke

Schmuck

Herd

Auto

Gemüse

Bälle

Frösche

Ballons

Blusen

Hotels

Wein

Vögel

Blüten

Schuhe

Schmuck

Getränke

Herd

Busch

Gemüse

Auto

Tabletten

Tabletten

Bälle

$\begin{array}{ll}\text { Butter } & \text { Mütze } \\ \text { Mütze } & \text { Butter } \\ \text { Mäuse } & \text { Post } \\ \text { Post } & \text { Mäuse } \\ \text { Pilze } & \text { Scheren } \\ \text { Scheren } & \text { Pilze } \\ \text { Flieger } & \text { Bier } \\ \text { Bier } & \text { Flieger } \\ \text { Blumen } & \text { Abdrücke } \\ \text { Abdrücke } & \text { Blumen } \\ & \\ \text { Panther } & \text { Pralinen } \\ \text { Pralinen } & \text { Panther }\end{array}$




\section{Prime sentence}

Leon hat Adler auf dem Berggipfel entdeckt.

Anja hat Saft auf dem Straßenfest verkauft.

Mona hat Jacken gegen die Kälte organisiert.

Linda hat die Brille aus Versehen zerbrochen.

Sina hat die Sprünge der Balletttänzer bewundert.

Simon hat die Hitze in Australiens Steppe gefürchtet.

Iris hat eine Birne vom Baum geholt.

Dieter hat die Würste neben den Grill gelegt.

Hubert hat die Stiefel im Gewächshaus gelassen.

Der Rennfahrer hat die Nässe bei dem Rennen unterschätzt.

Magda hat eine Creme gegen die Sonne eingepackt.

Der Richter hat die Robe vor dem Prozess überprüft.

Luna hat Tücher im Kindergarten gefärbt.

Der Fotograf hat den Blitz am Set eingestellt.

Astrid hat Rezepte für einen Auflauf gesucht.

Torsten hat seine Fotos nach Motiv sortiert.

Die Verkäuferin hat Tüten ins Regal sortiert.

Mirko hat Kisten in den Umzugswagen geräumt.

Der Tennisspieler hat seinen Schläger nach dem

Turnier abgeben müssen.

Der Imker hat Wachs für die Analyse eingeschickt.
Related probe word

Unrelated probe word

$\begin{array}{ll}\text { Schnee } & \text { Lose } \\ \text { Lose } & \text { Schnee } \\ \text { Decken } & \text { Spiegel } \\ \text { Spiegel } & \text { Decken } \\ \text { Kostüme } & \text { Spinnen } \\ \text { Spinnen } & \text { Kostüme } \\ \text { Katze } & \text { Zange } \\ \text { Zange } & \text { Katze } \\ \text { Tomaten } & \text { Kurve } \\ \text { Kurve } & \text { Tomaten }\end{array}$

Schirm

Akte

Akte

Eier

Stativ

Nudeln

Hemden

Reis

Möbel

Pokal

Schirm

Stativ

Eier

Hemden

Nudeln

Möbel

Reis

Honig

Honig

Pokal 